\title{
PENGARUH IKLAN ONLINE MELALUI INSTAGRAM TERHADAP KEPUTUSAN PEMBELIAN BAGI PENINGKATAN PENJUALAN PRODUK KULINER LOKAL
}

\author{
Adhita Maharani Dewi \\ Universitas Kristen Surakarta \\ adhitamaharanidewi@uks.ac.id
}

\begin{abstract}
This study examined the Influence of Online advertising Via Instagram consisting of attitude towards the ad, ad recall and clik throught rates, against the decision of the purchase for the increased sales of Local Culinary Products. The purpose of this research was to describe the activity of young culinary entrepreneurs in social media that is instagram the current phenomenon of increased numbers of their accounts as well as how much influence the activity of the young culinary entrepreneurs on instagram can increase sales of local culinary products. With the right marketing activities on instagram can be beneficial against purchasing decisions so that it will enhance local culinary products sales. This research use questionnaire as a research instrument to get the data from the consumer Pasta Resembles and Markobar1996. In this study the criteria of respondennya i.e. the respondent must as followers, and never eat the product by the number of samples planned is 200 people. Analysis tools that will be used Multiple Linear Regression is to test the influence of the dependent and independent variables. The results of the data processing has been done the third factor i.e. attitude towards the advertising, ad recall and click rates are throught to have simultaneous and partial influence against the purchasing decision. Factor Ad Recall is the most dominant factor and Factor Click Throught Rates is the factor that has the most influence diminished purchasing decisions.
\end{abstract}

Keywords : attitude, click, recall, advertising online, purchase decisions.

\begin{abstract}
Abstrak
Penelitian ini akan meneliti tentang Pengaruh Iklan Online Melalui Instagram yang terdiri dari attitude towards the ad, ad recall dan clik throught rates, Terhadap Keputusan Pembelian Bagi Peningkatan Penjualan Produk Kuliner Lokal. Tujuan penelitian ini untuk menggambarkan aktivitas pengusaha kuliner muda di media sosial yaitu instagram yang saat ini jumlah akunnya semakin bertambah banyak serta seberapa jauh pengaruh aktivitas pengusaha kuliner muda di instagram dapat meningkatkan penjualan produk kuliner lokal. Dengan melakukan aktivitas pemasaran yang tepat di instagram dapat bermanfaat terhadap keputusan pembelian sehingga akan meningkatkan penjualan produk kuliner lokal. Penelitian ini menggunakan kuesioner sebagai instrumen penelitian untuk mendapatkan data dari konsumen Pasta Buntel dan Markobar1996. Dalam penelitian ini kriteria respondennya yaitu responden harus sebagai followers, serta pernah makan produk tersebut dengan jumlah sampel yang direncanakan adalah 200 orang. Alat analisis yang akan digunakan adalah Regresi Linear Berganda untuk menguji pengaruh variabel independen dan dependen. Hasil dari pengolahan data yang telah dilakukan ketiga faktor yaitu attitude towards the advertising, ad recall dan click throught rates memiliki pengaruh secara simultan dan parsial terhadap Keputusan Pembelian. Faktor Ad
\end{abstract}


Recall merupakan faktor yang paling dominan dan Faktor Click Throught Rates merupakan faktor yang memiliki pengaruh paling kecil terhadap Keputusan Pembelian.

Kata Kunci : attitude, click, recall, iklan online, keputusan pembelian.

\section{PENDAHULUAN}

\section{Latar Belakang Masalah}

Peran pemuda dalam memajukan negara Indonesia dari segala sendi kehidupan sangat diperlukan. Terutama dalam bidang peningkatan ekonomi, banyak cara yang bisa dilakukan untuk meningkatkan perekonomian, salah satunya dengan berwirausaha. Wirausahawan muda mulai bermunculan di daerah - daerah dan semuanya memiliki karakteristik usaha yang berbeda. Sedangkan jenis usaha yang paling digemari adalah usaha kuliner, mereka memilih usaha tersebut dengan asumsi setiap hari orang butuh makan. Menjamurnya bisnis makanan membuat persaingan semakin ketat, sehingga setiap pelaku usaha harus memaksimalkan ide dan kreatifitasnya untuk menghasilkan produk yang diminati oleh konsumen. Salah satu cara untuk meningkatkan penjualan adalah melakukan pemasaran.

Pemasaran sendiri bisa dilakukan melalui tiga macam media. Media cetak, media audio visual dan media online. Media cetak selain koran dan majalah bisa berupa flyer, brosur, pamflet dan spanduk. Media audio visual atau media elektronik merupakan media yang relatif mahal, dan tidak terjangkau untuk pengusaha pemula, karena mengiklankan suatu produk melalui media elektronik membutuhkan biaya yang cukup besar. Sedangkan media yang paling murah dan akhir - akhir ini sering digunakan adalah media sosial. Neti (2011) mengatakan bahwa "pemasaran media sosial adalah salah satu upaya untuk mengoptimalkan media sosial guna membujuk konsumen kepada satu perusahaan, produk atau jasa yang berharga". Pemasaran media sosial adalah proses strategis dan metodis untuk membangun pengaruh perusahaan, reputasi dan merek dalam komunitas pelanggan potensial, pembaca dan atau pendukung.

Media sosial saat ini merupakan alat promosi dan komunikasi yang paling banyak digunakan karena berdampak sangat signifikan terhadap perkembangan bisnis karena memiliki kelebihan diantaranya banyak pengguna serta tidak memerlukan biaya untuk membuat akun di sebuah media sosial. "Pengguna internet di Indonesia mencapai 82 juta orang dengan capaian tersebut Indonesia menduduki peringkat 8 besar dunia" (https://kominfo.go.id, diakses 3 Maret 2017). Salah satu media sosial yang sedang 
digemari dan banyak penggunanya adalah Instagram. "Pengguna media sosial instagram di Indonesia termasuk yang terbanyak di dunia bersama Jepang dan Brazil" (http://www.antaranews.com, diakses 3 Maret 2017). Dan mayoritas pengguna instagram adalah anak muda yang berpendidikan tinggi serta menggunakan ponsel pintar. Dapat disimpulkan bahwa pengusaha muda sudah tidak asing lagi bahkan sudah banyak yang mengggunakan fasilitas media sosial. Media sosial juga bisa dijadikan sebagai sarana interaksi dengan konsumen (Mershon, 2011).

Media sosial instagram menyediakan beragam fasilitas yang dapat dimanfaatkan pelaku bisnis bagi kelancaran usahanya. Penelitian Eryta (2013) "instagram merupakan aplikasi media sosial yang kehadirannya semakin dimaksimalkan sebagai media komunikasi pemasaran. Instagram memberikan peran penting bagi pelaku bisnis yang menggunakannya sebagai media pemasarannya, diantaranya adalah instagram sebagai media promosi yang dianggap efektif oleh para informan, yang kedua instagram sebagai media komunikasi antara pelaku bisnis dengan para konsumennya. Dan yang terakhir, instagram memberikan dampak terhadap peningkatan penjualan pada bisnis mereka”.

Kota Solo terkenal dengan makanan khasnya, diantaranya tengkleng, sate kambing, nasi liwet, wedang ronde, dawet, dan lain - lain. Selain makanan yang sudah lama dikenal tersebut, ada varian baru yang muncul di Solo yaitu Pasta Buntel dan Markobar. Pasta Buntel sendiri merupakan makanan yang menggabungkan olahan pasta dengan rasa tradisional Solo dan menggunakan daun sebagai kemasannya. Sedangkan Markobar adalah martabak manis atau terang bulan yang memiliki 8 toping. Dua varian baru dalam usaha kuliner ini semuanya dijalankan oleh anak muda dan sekarang menjadi ciri khas kota Solo. Dikatakan ciri khas sebab saat berkunjung ke kota Solo belum lengkap jika tidak menyempatkan diri mengincipi makanan tersebut.

Pasta Buntel dan Markobar menggunakan media online untuk memasarkan produknya. Salah satu media yang digunakan adalah instagram, pelaku usaha ini membuat akun dengan nama pastabuntel dan markobar1996. Banyak kegiatan yang mereka lakukan dalam rangka mempromosikan produknya misalnya dengan mengunggah foto produk, foto konsumen yang sedang meikmati produk mereka, menambah jumlah followers, memberikan tanggapan kepada followers yang mengomentari foto mereka, mengiklankan akun mereka melalui akun kulinersolo dan lain 
sebagainya. Kegiatan yang mereka lakukan di media sosial instagram ini menarik untuk diteliti lebih lanjut, terutama peran instagram dalam meningkatkan penjualan produk.

Pasta Buntel sendiri memiliki 215 kiriman (bisa berupa foto maupun video), 4530 pengikut dan mengikuti 240 akun. Sedangkan Markobar1996 memiliki 375 kiriman, 42600 pengikut dan mengikuti 63 akun. Setiap hari pengikut dan kiriman mereka semakin bertambah. Dan berdasarkan data tersebut, maka perlu dilakukan penelitian mengenai pengaruh iklan online melalui instagram terhadap keputusan pembelian bagi peningkatan penjualan produk kuliner lokal.

\section{Perumusan Masalah}

Berdasarkan latar belakang permasalahan yang telah dijelaskan di atas, maka dapat dirumuskan permasalahan dalam penelitian ini sebagai berikut :

1. Apakah variabel attitude towards the ad, ad recall dan clik-through pada iklan online melalui instagram secara simultan berpengaruh positif dan signifikan terhadap keputusan pembelian produk kuliner lokal?

2. Apakah variabel attitude towards the ad, ad recall dan clik-through pada iklan online melalui instagram secara parsial berpengaruh positif terhadap keputusan pembelian produk kuliner lokal?

3. Variabel manakah diantara attitude towards the ad, ad recall dan clik-through yang mempunyai pengaruh dominan terhadap keputusan pembelian produk kuliner lokal?

\section{Tujuan Penelitian}

Tujuan yang ingin dicapai dalam penelitian ini untuk mengetahui :

1. Menguji pengaruh iklan di media instagram terhadap keputusan pembelian.

2. Memberikan gambaran tentang aktifitas pengusaha kuliner muda yang beriklan di media instagram.

\section{Manfaat Penelitian}

Manfaat penelitian adalah berikut ini :

1. Bagi pembangunan dan pengembangan IPTEKS, untuk menambah dan memperdalam pengetahuan di bidang ilmu ekonomi pada umumnya dan manajemen perusahaan pada khususnya pada pemusatan masalah pemasaran melalui media social. 
2. Bagi pelaku usah hasil penelitian ini dapat membantu mengetahui aktivitas di media sosial dalam upaya meningkatkan pemasaran produk usahanya.

3. Bagi masyarakat umum, penulis berharap publikasi tulisan ini dapat berguna untuk penelitian selanjutnya.

\section{LANDASAN TEORI}

Penelitian ini meneliti pengaruh iklan online melalui instagram terhadap keputusan pembelian bagi peningkatan penjualan produk kuliner lokal.

\section{Iklan Online}

E-Marketing menurut Armstrong dan Kotler (2004) adalah "suatu pasar baru melalui jaringan internet yang dijadikan sebagai upaya mengkomunikasikan suatu perusahaan, promosi, menjual produk dan jasa melalui jaringan internet”. Selain itu pemasar juga menggunakan media sosial sebagai salah satu media pemasarannya.

Menurut Andreas Kaplan dan Michael Haenlein (2010), "media sosial didefinisikan sebagai sebuah kelompok aplikasi berbasis internet yang dibangun atas dasar ideologi dan teknologi Web 2.0". Web 2.0 adalah dasar platform media sosial. Media sosial sendiri terdiri dari bermacam-macam bentuk yang beragam seperti social network, facebook, forum internet, kaskus, weblogs, social blogs, whatsapp, micro blogging, wikis, BBM, podcasts, gambar, video, rating dan bookmark sosial.

Menurut Erdogmus \& Çiçek (2012) pemasaran media sosial didefinisikan sebagai proses yang memberdayakan individu untuk mempromosikan situs web, produk, atau jasa mereka melalui saluran sosial online dan memasuki sebuah komunitas yang jauh lebih besar yang mungkin belum tersedia melalui saluran tradisional.

Menurut Lim et, al (2011) sudah ada beberapa studi yang telah mengambil pembahasan mengenai efektivitas iklan internet dalam dekade terakhir. Umumnya untuk mengetahui seberapa efektifkah iklan online tersebut. Ada beberapa variabel yang bisa digunakan untuk mengukur keefektifan suatu iklan online yaitu ad recall, online advertising awards, brands awereness, CTR (Click Throught Rates), dan attitude towards the ad. Dari pengukuran efektifitas tersebut hanya ad recall, attitude towards the $a d$, dan CTR adalah tiga hal yang menjadi fokus dalam penelitian ini. Ketiga langkah ini dinilai dengan kemampuan mereka untuk memprediksi keputusan pembelian online. 
1. Attitude towards the ad : menurut Kotler dan Keller (2009) "sikap adalah evaluasi yang dilakukan dalam waktu lama tentang yang disukai atau tidak disukai seseorang, perasaan emosional dan kecenderungan tindakan terhadap beberapa objek atau ide". Sikap menempatkan orang dalam kerangka pemikiran mengenai menyukai atau tidak menyukai sesuatu, mengenai mendekati atau menjauhinya dan lain sebagainya.

2. Ad recall : menurut Hening (2014) maksud dari ability to recall online ads adalah "kemampuan seorang konsumen untuk mengingat terhadap iklan yang sudah dilihatnya, baik dari media televisi, radio, maupun internet”. Sedangkan fokus dari penelitian ini adalah media internet melalui media sosial yaitu instagram.

3. Click Throught Rates (CTR) : tujuan dari CTR adalah untuk mengetahui tanggapan maupun review iklan dari para pengunjung dalam suatu media online. Dengan adanya metode CTR pemasar bisa mengetahui reaksi maupun respon dari pengunjung akunnya dan mulai merencanakan strategi selanjutnya untuk mendapatkan respon positif atas produk yang dikampanyekan di instagram.

\section{Sejarah Instagram}

Perusahaan Burbn, Inc. merupakan salah satu vendor aplikasi untuk telepon genggam yang berdiri pada tahun 2010. Pada awalnya Burbn, Inc. sendiri memiliki fokus yang terlalu banyak di dalam HTML5 peranti bergerak, namun kedua CEO, Kevin Systrom dan Mike Krieger memutuskan untuk lebih fokus pada satu hal saja. Setelah satu minggu mereka mencoba untuk membuat sebuah ide yang bagus, pada akhirnya mereka membuat sebuah versi pertama dari Burbn, namun di dalamnya masih ada beberapa hal yang belum sempurna. Versi Burbn yang sudah final, aplikasi yang sudah dapat digunakan iPhone yang isinya terlalu banyak dengan fitur. Sulit bagi Kevin Systrom dan Mike Krieger untuk mengurangi fitur yang telah ada, dan memulai lagi dari awal, namun akhirnya mereka hanya memfokuskan pada bagian foto, komentar, dan juga kemampuan untuk menyukai sebuah foto. Itulah yang akhirnya menjadi Instagram (http://www.mediamasha.com diakses 3 Maret 2017).

Instagram memiliki fitur-fitur yang sangat menunjang penggunanya untuk mengiklankan produk yang mereka jual dan kemudian menuai banyak followers dan like. Pelaku bisnis muda memanfaatkan fitur yang ada sebagai komunikasi dengan para pengikut akunnya. Cara berkomunikasi bisa dengan komentar pada foto yang sudah diupload. 


\section{Keputusan Pembelian}

Menurut Kotler dan Keller (2009) "keputusan pembelian merupakan suatu proses dimana konsumen melewati lima tahap yaitu : pengenalan masalah, pencarian informasi, evaluasi alternatif, keputusan pembelian dan perilaku pasca pembelian”.

\section{Penelitian Terdahulu}

Hening (2014) meneliti tentang pengaruh iklan online terhadap keputusan pembelian. Dari penelitian ini iklan melalui media sosial berpengaruh positif terhadap keputusan pembelian. Dan ad recall merupakan variabel yang paling dominan.

Megawati (2014) meneliti tentang pengaruh iklan online terhadap keputusan pembelian. Hasil penelitian menunjukkan bahwa iklan online mempunyai hubungan yang positif terhadap keputusan pembelian.

Menurut Lim, et al (2011) dalam penelitiannya yang berjudul The Effectiveness of Online Advertising in Purchase Decision : Liking, Recall and Click menyatakan bahwa "variabel liking, recall dan click memberi pengaruh yang signifikan positif terhadap keputusan pembelian. Dan variabel recall merupakan variabel yang paling dominan".

\section{Roadmap Pengaruh Iklan Online Melalui Instagram Terhadap Keputusan Pembelian Bagi Pengembangan Penjualan Produk Kuliner Lokal}

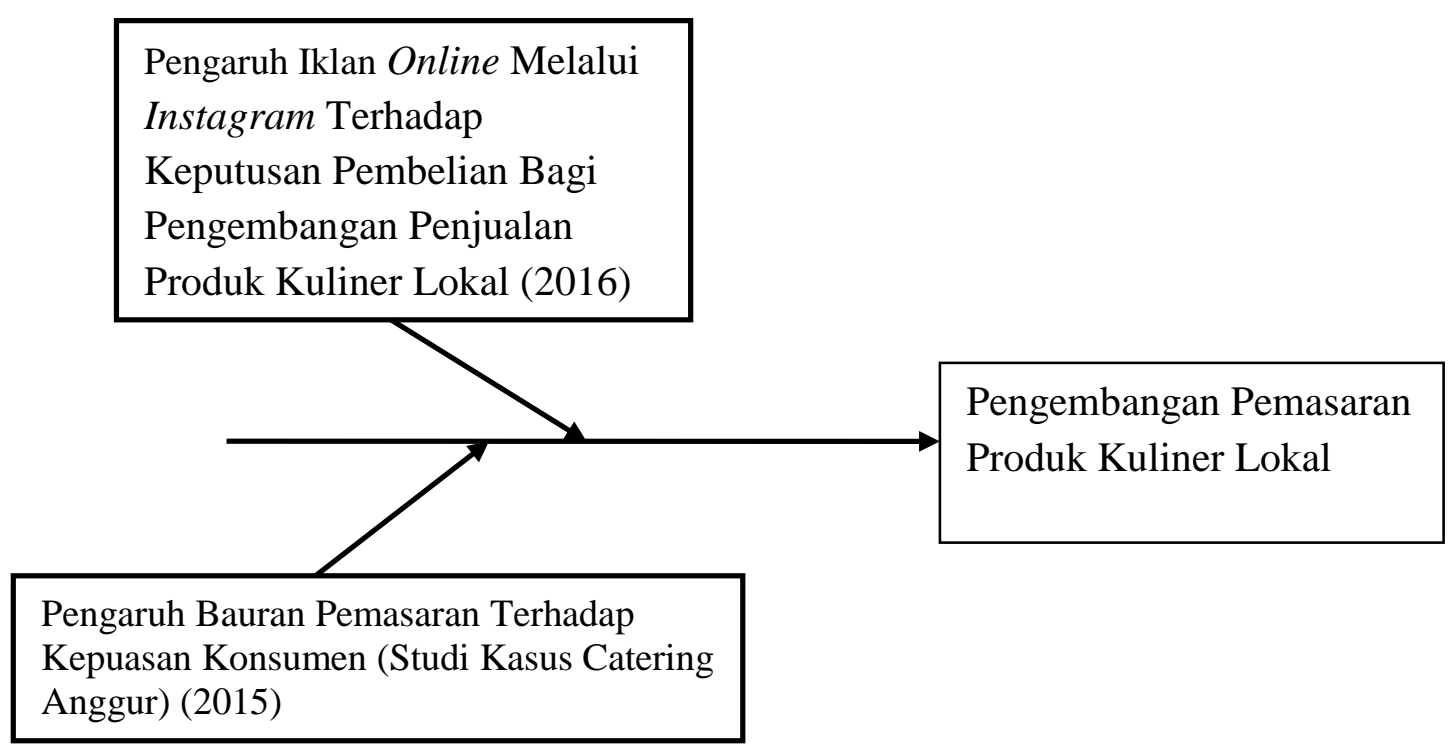




\section{Gambar 1. Pengaruh Iklan Online Melalui Instagram Terhadap Keputusan Pembelian Bagi Pengembangan Penjualan Produk Kuliner Lokal.}

\section{Hipotesis}

Ada beberapa variabel yang bisa digunakan untuk mengukur keefektifan suatu iklan online yaitu ad recall, online advertising awards, brands awereness, CTR (Click Throught Rates), dan attitude towards the ad. Dari pengukuran efektifitas tersebut ad recall, attitude towards the ad, dan CTR adalah tiga hal yang menjadi fokus dalam penelitian ini. Ketiga langkah ini dinilai dengan kemampuan mereka untuk memprediksi keputusan pembelian online.

1. Attitude towards the ad merupakan hal yang sangat penting bagi pemasar, karena konsumen akan memiliki sikap yang berbeda-beda terhadap produk atau jasa. Semakin baik sikap konsumen pada iklan online maka keputusan pembelian akan semakin meningkat. Untuk membuat sikap konsumen baik terhadap iklan, maka pemasar harus bisa membuat iklan yang menarik. Melalui media sosial instagram, pemasar dapat memasang foto produk atau jasanya dengan proses pengeditan yang telah disediakan, sehingga foto yang ditampilkan menjadi lebih menarik. Lewat foto ini nanti bisa merubah sikap konsumen menjadi ingin tahu dan kemudian melakukan pembelian.

2. Ad recall merupakan variabel yang paling dominan, dikarenakan followers setiap hari mengikuti update foto maupun video yang diupload oleh pemasar. Karena setiap hari melihat dan membaca iklan tersebut, maka ketika suatu saat konsumen ingin makan martabak manis yang diingat adalah Markobar1996.

3. Click Throught Rates (CTR) menunjukkan jumlah like pada foto yang diunggah dalam akun instagram. Like adalah fitur yang ada dalam aplikasi instagram. Apabila seorang followers mengklik like pada update foto pemasar, maka hal tersebut merupakan bentuk komunikasi.

Berdasarkan uraian tersebut, maka dapat diformulasikan rumusan hipotesis sebagai berikut :

H1 : Variabel attitude towards the ad, ad recall dan clik-through pada iklan online melalui instagram secara simultan berpengaruh positif dan signifikan terhadap keputusan pembelian bagi peningkatan penjualan produk kuliner lokal. 
H2: Variabel attitude towards the ad, ad recall dan clik-through pada iklan online melalui instagram secara parsial berpengaruh positif terhadap keputusan pembelian bagi peningkatan penjualan produk kuliner lokal.

H3: Ad Recall mempunyai pengaruh dominan terhadap keputusan pembelian bagi peningkatan penjualan produk kuliner lokal.

\section{METODE PENELITIAN}

\section{Tahapan Penelitian}

Skema tahapan penelitian dapat dilihat sebagai berikut

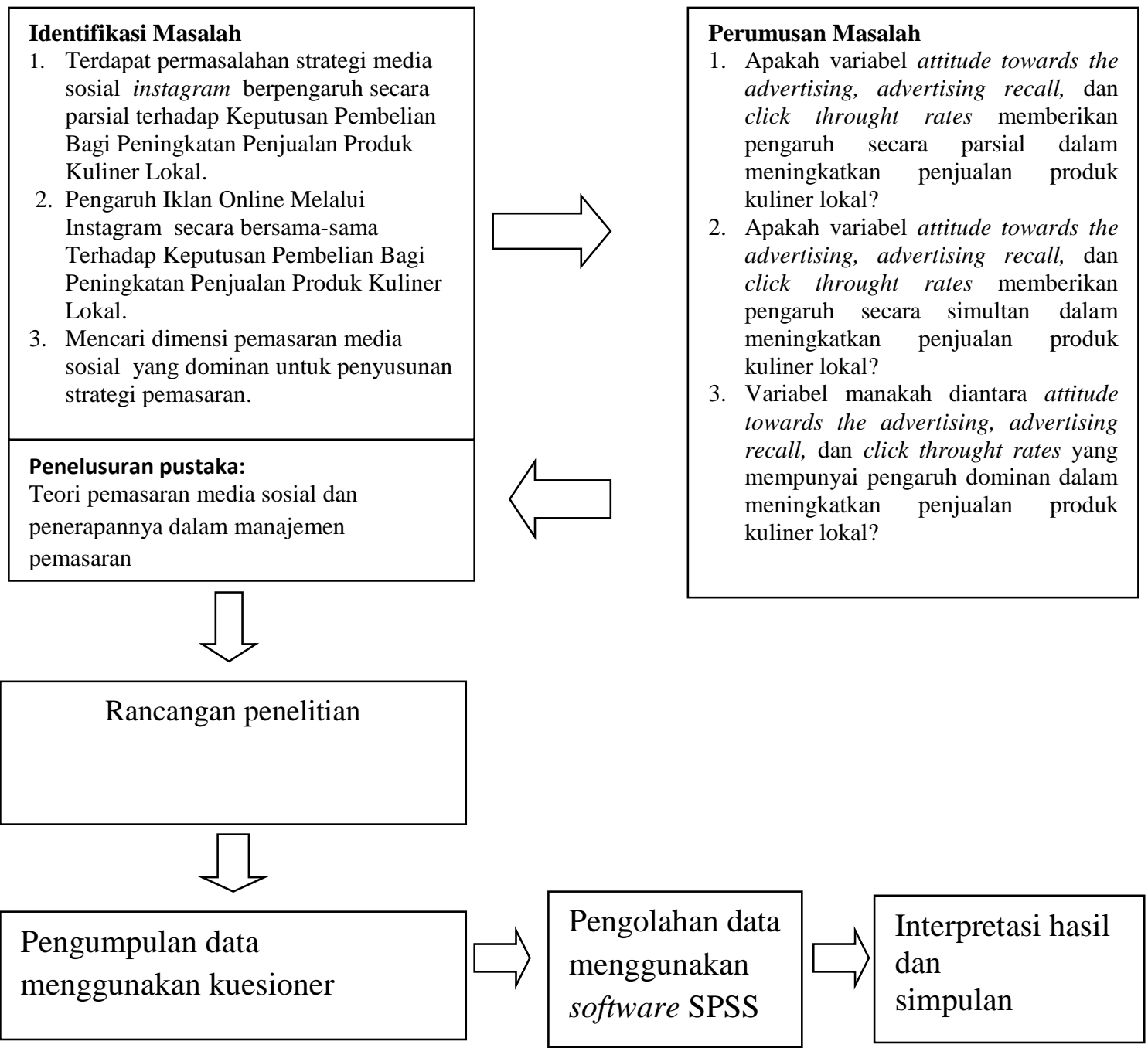

Obyek dalam penelitian ini adalah konsumen pengguna media sosial instagram di kota Surakarta dan mengikuti salah satu akun instagram pastabuntel atau markobar1996. 


\section{Variabel Yang Diukur}

\section{Variabel Dependen}

Variabel yang dipengaruhi oleh variabel independen, dalam penelitian ini variabel dependennya adalah Keputusan Pembelian Bagi Peningkatan Penjualan Produk Kuliner Lokal.

\section{Variabel Independen}

Variabel yang mempengaruhi variabel dependen, dalam penelitian ini variabel independennya adalah Iklan Online Melalui Instagram yang terdiri dari attitude towards the ad, ad recall dan click Trought Rates.

\section{Model}

Model pengujian hipotesis

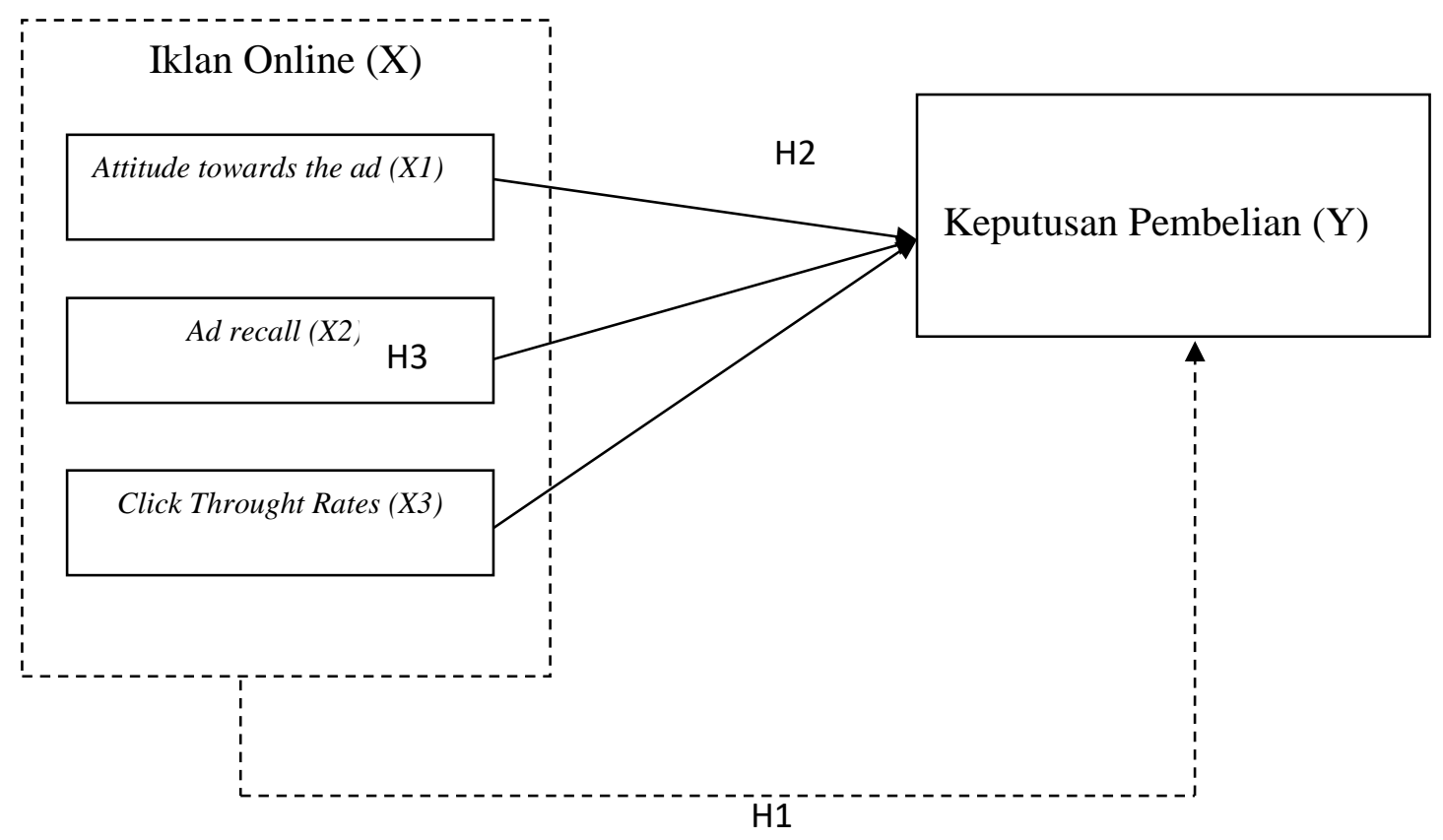

Gambar 3. Model Pengujian hipotesis

\section{Rancangan Penelitian}

Rancangan penelitian yang akan dilaksanakan dalam penelitian ini sebagai berikut : 

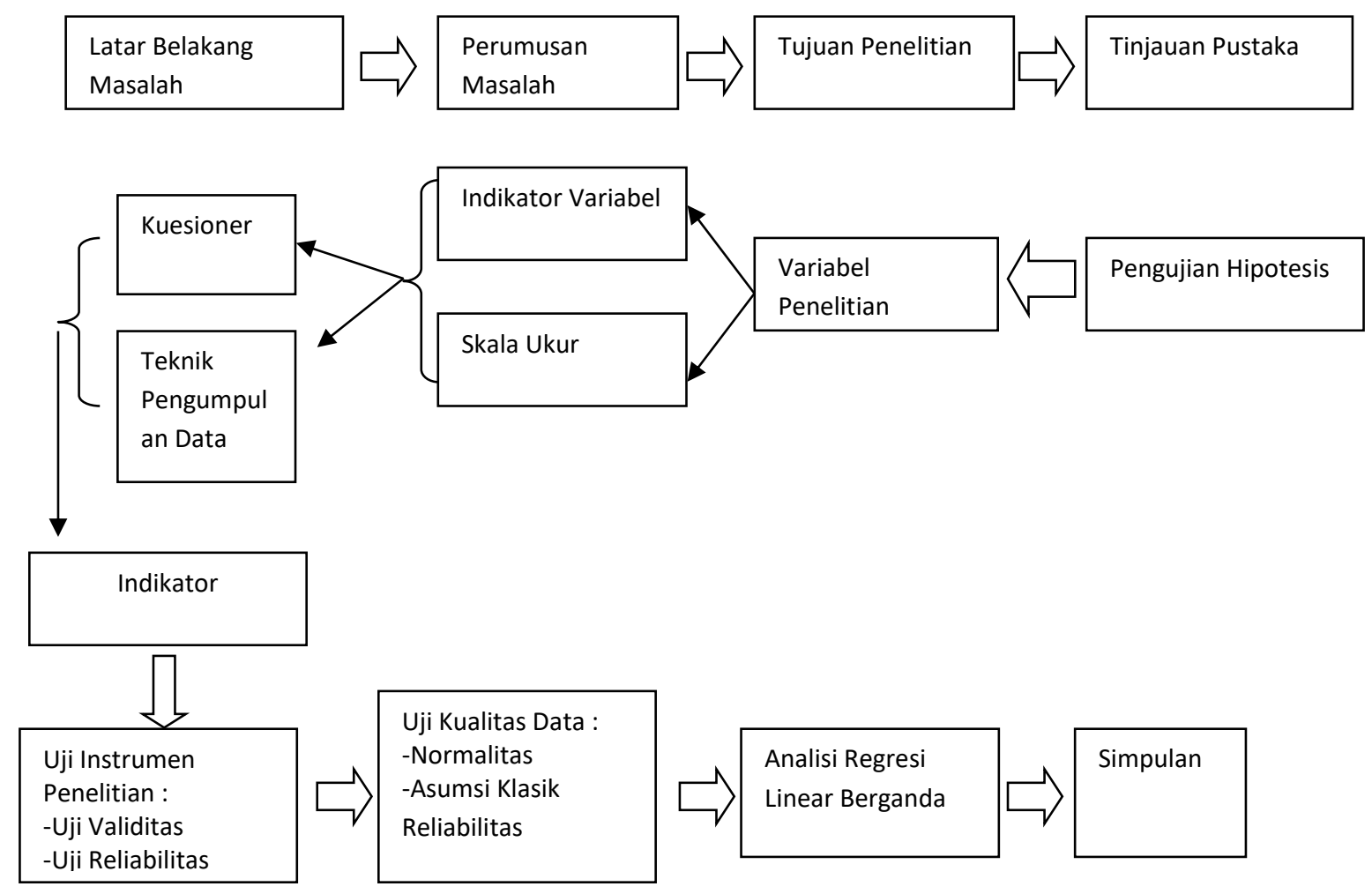

Gambar 4. Skema Rancangan Penelitian Pengaruh Iklan Online Melalui Instagram Terhadap Keputusan Pembelian Bagi Peningkatan Penjualan Produk Kuliner Lokal.

\section{Populasi Dan Sampel}

Populasi dalam penelitian ini adalah konsumen pengguna media sosial yang memiliki akun instagram serta mengikuti salah satu akun instagram pastabuntel dan markobar1996 atau mengikuti akun keduanya. Sampel yang diambil sebanyak 200 responden. Pemilihan sampel dilakukan menggunakan metode purposive sampling, yaitu pengambilan sampel dengan terlebih dahulu melakukan pertimbangan tertentu yang umumnya disesuaikan dengan tujuan atau masalah penelitian (Nur Indriantoro, 2002:131). Dua pertanyaan yang menjadi seleksi reponden sesuai dengan penelitian adalah apakah responden menggunakan media sosial instagram lebih dari satu kali dalam seminggu. Pertanyaan berikutnya apakah responden mengikuti satu akun instagram pastabuntel atau markobar1996 di media sosial. Jika jawaban kedua pertanyaan tersebut positif maka responden dapat dikatakan layak untuk diberi kuesioner. 


\section{Teknik Pengumpulan Data}

Teknik pengumpulan data yang digunakan dalam penelitian ini menggunakan kuesioner tertutup dengan memberikan alternatif jawaban yang sudah tersedia. Sedangkan responden yang bersangkutan cukup memberikan tanda silang (X) pada pilihan jawaban yang ada pada kuesioner.

Dengan menggunakan skala Likert untuk mengukur sikap, pendapat, dan persepsi seseorang atau kelompok organisasi tentang fenomena sosial dan mempunyai gradasi dari sangat positif sampai negatif (Sugiyono, 2004). Alternatif jawaban disesuaikan dengan Skala Likert yang dibuat menjadi lima alternatif jawaban. Analisa diberi bobot dan skor masing-masing jawaban dengan kriteria sebagai berikut: 1) Sangat Tidak Setuju, 2) Tidak Setuju, 3) Netral, 4) Setuju, 5) Sangat Setuju.

\section{Pengukuran Variabel.}

Variabel attitude towards the advertising diukur dengan menggunakan indikator:

1. Disukai

2. Ketertarikan

3. Manfaat

Variabel ad recall diukur dengan menggunakan indikator:

1. Daya ingat

2. Desain produk

3. Cara mengingat

Variabel click throught rates diukur dengan menggunakan indikator:

1. Klik

2. Rutinitas klik

Variabel Keputusan Pembelian Bagi Peningkatan Penjualan Produk Kuliner Lokal diukur dengan menggunakan indikator:

1. Pengenalan masalah

2. Pencarian informasi

3. Evaluasi alternatif

4. Keputusan pembelian

5. Perilaku pasca pembelian 


\section{HASIL DAN PEMBAHASAN}

\section{Uji Instrumen Penelitian}

\section{Uji Validitas}

Uji validitas ini dilakukan untuk mengetahui sejauh mana ketepatan dan kecermatan suatu alat ukur dalam melakukan fungsi ukurannya. "Uji validitas dilakukan agar instrumen yang digunakan dalam hal ini kuesioner mampu mengukur apa yang seharusnya diukur" (Sugiyono, 2004: 109). Metode yang digunakan adalah korelasi produk momen Pearson, untuk mempermudah perhitungannya, uji validitas dalam penelitian ini dilakukan dengan bantuan SPSS. Suatu item pertanyaan akan dikatakan valid apabila nilai rxy> rtabel dan suatu item pertanyaan akan dikatakan tidak valid apabila rxy< rtabel (Sugiyono, 2004: 110).

\section{Uji Reliabilitas}

Uji reliabilitas adalah indeks yang menunjukkan sejauh mana suatu alat pengukur dapat dipercaya atau dapat diandalkan dan sejauh mana hasil pengukurannya tetap konsisten bila dilakukan pengukurannya dua kali atau lebih terhadap gejala yang sama dengan alat ukur yang sama dalam hal ini reliabilitas dilihat dari Alpha Cronbach. Nilai alpha antara 0,8 - 1,0 dikategorikan reliabilitas baik, nilai 0,6-0,79 dikategorikan reliabilitas dapat diterima dan jika alphanya kurang dari 0,6 dikategorikan reliabilitas kurang baik. Pengujian dilakukan dengan menggunakan teknik Alpha Cronbach (Sugiyono, 2004: 110).

\section{Uji Asumsi klasik}

Menurut Gujarati (2007), selain asumsi kenormalan distribusi data, sebuah model regresi harus memenuhi 3 asumsi klasik yaitu bebas dari fenomena multikolinieritas, heteroskedastisitas dan autokorelasi. Tidak terpenuhinya ketiga asumsi ini menyebabkan model regresi bersifat lancung dan menyesatkan. Uji asumsi klasik diuraikan menjadi 4 bagian, antara lain :

\section{Uji Normalitas Data}

Uji normalitas ini bertujuan untuk menguji apakah data yang dipakai dalam penelitian ini terdistribusi dengan cara normal atau tidak. Model regresi yang baik adalah memiliki distribusi data normal atau mendekati normal. Untuk mengetahui hasil uji normalitas digunakan metode grafik, yaitu menggunakan grafik normal P-P Plot. "Distribusi normal akan membentuk satu garis lurus diagonal dan ploting normal, maka 
garis yang menggambarkan data sesungguhnya akan mengikuti garis diagonalnya". (Ghozali, 2009:74)

\section{Uji Multikolinieritas}

Uji multikolinieritas digunakan untuk menguji model regresi ditemukan adanya korelasi antar variabel bebas (independen). Model regresi yang baik seharusnya tidak terjadi korelasi korelasi diantara variabel independen. Jika variabel independen saling berkorelasi, maka variabel-variabel ini tidak ortogonal. "Variabel ortogonal adalah variabel independen yang nilai korelasi antar sesama variabel independen sama dengan nol" (Ghozali, 2009 : 91).

\section{Uji Heteroskedastisitas}

Asumsi ini adalah varian residual yang bersifat homokedastisitas atau bersifat konstan. Apabila terjadi pelanggaran asumsi klasik tersebut, maka varian rsidual tidak lagi bersifat konstan (disebut heteros). Dan apabila model yang mengandung heteros diestimasi, varian estimasi tidak lagi minimum, kendati pun estimator itu sendiri tidak bias. Cara mendeteksi gangguan heteroskedastisitas adalah dengan melihat pola diagram pencar residual (Sugiyono: 2004) .

\section{Uji Autokorelasi}

Pengertian autokorelasi sebagai antar anggota rentetan observasi dalam rentetan waktu (data time series) atau waktu tertentu (data cross sectional). Masalah ini timbul karena residual atau kesalahan penganggu, tidak bebas dari suatu observasi lainnya. Uji untuk mengetahui adanya autokorelasi adalah uji Durbin Watson.

Beberapa ada tidaknya adanya autokorelasi (Ghozali, 2009:96) adalah :

1. Bila nilai DW terletak diantara du dan $4-d u(d u<D W<4-d u)$, maka koefisien korelasi sama dengan nol, berarti tidak ada korelasi.

2. Bila nilai DW lebih rendah dari dl (DW < dl), maka koefisien auto- korelasi lebih besar nol, berarti ada autokorelasi positif.

3. Bila nilai DW lebih besar dari $4-\mathrm{dl}$ (DW > $4-\mathrm{dl}$ ), maka koefisien dari autokorelasi lebih kecil daripada nol, berarti ada autokorelasi negatif.

4. Bila nilai DW terletak antara du dan $\mathrm{dl}(\mathrm{du}<\mathrm{DW}<\mathrm{dl})$ atau terletak antara 4-du dan 4-dl (4-du $<$ DW < 4-dl), maka hasilnya tidak dapat disimpulkan. 


\section{Uji Hipotesis}

Pengujian hipotesis pertama, kedua dan ketiga ini dilakukan dengan menggunakan analisis regresi berganda analisis untuk mengukur Pengaruh Iklan Online Melalui Instagram yaitu attitude towards the advertising, ad recall dan click throught rates bagi Peningkatan Penjualan Produk Kuliner Lokal dengan menggunakan tingkat signifikansi ( $\alpha$ ) sebesar 5\%. (Sugiyono: 2004).

\section{Analisa Regresi}

Tabel regresi berganda "Pengaruh Iklan Online Melalui Instagram Terhadap Keputusan Pembelian Bagi Peningkatan Penjualan Online”.

\section{Tabel 1 : Regresi berganda}

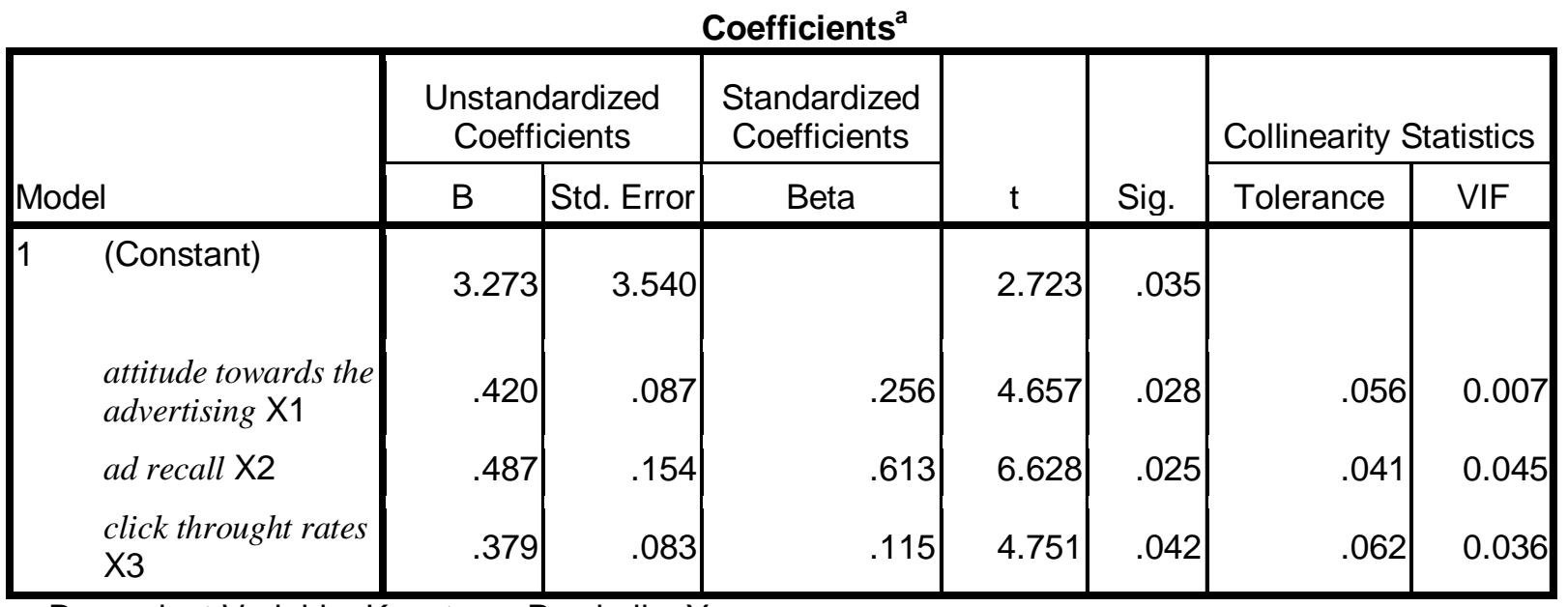

a. Dependent Variable: KeputusanPembelianY

Berdasarkan tabel diatas faktor attitude towards the advertising, ad recall dan click throught rates memiliki hubungan yang positif terhadap Keputusan Pembelian. Hubungan positif ini menunjukan bahwa faktor attitude towards the advertising, ad recall dan click throught rates memiliki pengaruh terhadap Keputusan Pembelian.

\section{Uji R Square}

Tabel di bawah ini akan menunjukan besarnya pengaruh faktor attitude towards the advertising, ad recall dan click throught rates memiliki pengaruh terhadap Keputusan Pembelian. 
Tabel 2 : Model summary

\begin{tabular}{|c|c|c|c|c|c|}
\hline Model & $\mathrm{R}$ & R Square & $\begin{array}{l}\text { Adjusted } \\
\text { R Square }\end{array}$ & $\begin{array}{l}\text { Std. Error } \\
\text { of the } \\
\text { Estimate }\end{array}$ & Watson \\
\hline 1 & $769^{a}$ & .783 & .851 & .51263 & 1.657 \\
\hline
\end{tabular}

a. Predictors: (Constant), attitude towards the advertising X1, ad recall X2, click throught rates $\mathrm{X} 3$,

sndent Variable: KeputusanPembelianY

Besarnya R square $\left(r^{2}\right)$ adalah 0.783. angka tersebut dapat digunakan untuk melihat besarnya pengaruh faktor attitude towards the advertising, ad recall dan click throught rates terhadap Keputusan Pembelian dengan cara menghitung Koefisien Determinasi (KD) dengan mengunakan rumus sebagai berikut:

$\mathrm{KD}=r^{2} \times 100 \%$

$\mathrm{KD}=0.783 \times 100 \%$

$\mathrm{KD}=78.30 \%$

Angka tersebut mempunyai maksud bahwa pengaruh faktor attitude towards the advertising, ad recall dan click throught rates terhadap Keputusan Pembelian adalah $78.30 \%$ dan sisanya sebesar $21.7 \%(100 \%-78.30 \%)$ dipengaruhi oleh faktor lain.

Untuk mengetahui model regresi di atas sudah benar atau salah, diperlukan uji hipotesis.

Uji hipotesis menggunakan angka F sebagai mana tertera dalam tabel di bawah ini :

Tabel 3 : Uji F

\begin{tabular}{|c|c|c|c|c|c|c|}
\hline \multicolumn{7}{|c|}{ ANOVA $^{b}$} \\
\hline \multicolumn{2}{|c|}{ Model } & $\begin{array}{l}\text { Sum of } \\
\text { Squares }\end{array}$ & df & Mean Square & $\mathrm{F}$ & Sig. \\
\hline \multirow[t]{3}{*}{1} & Regression & 17.631 & 3 & 4.537 & 76.513 & $.000^{\mathrm{a}}$ \\
\hline & Residual & 27.536 & 96 & .358 & & \\
\hline & Total & 45.167 & 99 & & & \\
\hline
\end{tabular}

a. Predictors: (Constant), attitude towards the advertising X1, ad recall X2, click throught rates $\mathrm{X} 3$,

b. Dependent Variable: Keputusan Pembelian Y 
Hipotesisnya adalah sebagai berikut :

H1 : Ada hubungan linier antara attitude towards the advertising, ad recall dan click throught rates secara bersama-sama berpengaruh terhadap Keputusan Pembelian. H0 : Tidak ada hubungan linier antara attitude towards the advertising, ad recall dan click throught rates secara bersama-sama berpengaruh terhadap Keputusan Pembelian. Dari hasil penghitungan, didapatkan angka $\mathrm{F}$ penelitian sebesar 76.513> F tabel sebesar 2.14 sehingga $\mathrm{H} 0$ ditolak H1 diterima. Artinya ada hubungan liner antara attitude towards the advertising, ad recall dan click throught rates secara bersama-sama berpengaruh terhadap Keputusan Pembelian. Dengan demikian model regresi di atas sudah benar. Kesimpulanya adalah attitude towards the advertising, ad recall dan click throught rates secara bersama-sama berpengaruh terhadap Keputusan Pembelian. Besarnya pengaruh adalah $76.513 \%$

b. Uji t

Tabel di bawah ini akan menjelaskan bagai mana pengaruh attitude towards the advertising , ad recall, dan click throught rates secara bersama-sama berpengaruh terhadap Keputusan Pembelian.

Coefficients $^{a}$

\begin{tabular}{|c|c|c|c|c|c|c|c|}
\hline \multirow[b]{2}{*}{ Model } & \multicolumn{2}{|c|}{$\begin{array}{l}\text { Unstandardized } \\
\text { Coefficients }\end{array}$} & $\begin{array}{c}\text { Standardized } \\
\text { Coefficients }\end{array}$ & \multirow[b]{2}{*}{$\mathrm{t}$} & \multirow[b]{2}{*}{ Sig. } & \multicolumn{2}{|c|}{ Collinearity Statistics } \\
\hline & $B$ & Std. Error & Beta & & & Tolerance & VIF \\
\hline $1 \quad$ (Constant) & 3.273 & 3.540 & & 2.723 & .035 & & \\
\hline $\begin{array}{l}\text { attitude } \\
\text { towards the } \\
\text { advertising } \mathrm{X} 1\end{array}$ & .420 & .087 & .256 & 4.657 & .028 & .056 & 0.007 \\
\hline ad recall $\times 2$ & .487 & .154 & .613 & 6.628 & .025 & .041 & 0.045 \\
\hline $\begin{array}{l}\text { Click throught } \\
\text { rates } \times 3\end{array}$ & .379 & .083 & .115 & 4.751 & .042 & .062 & 0.036 \\
\hline
\end{tabular}

a. Dependent Variable: KeputusanPembelianY

Tabel 5 Uji t

1. Hubungan antara dengan attitude towards the advertising terhadap Keputusan Pembelian

Jadi berdasarkan perhitungan diperoleh angka $t$ penelitian sebesar $4.657>\mathrm{t}$ tabel 1.6607. oleh karena itu maka H0 ditolak dan H1 diterima. Artinya ada hubungan linier antara attitude towards the advertising dan Keputusan pembelian. 
2. Hubungan antara ad recall dengan keputusan Pembelian.

Hasil penghitungan SPSS diperoleh angka $\mathrm{t}$ sebesar 6.628. Jadi berdasarkan perhitungan diperoleh angka t penelitian sebesar 6.628>t tabel 1.6607. oleh karena itu maka $\mathrm{H} 0$ ditolak dan $\mathrm{H} 1$ diterima. Artinya ada hubungan linier antara Ad Recall dengan Keputusan Pembelian.

3. Hubungan antara click throught rates dengan Keputusan Pembelian.

Hasil penghitungan dengan SPSS diperoleh angka t sebesar 4.751. Jadi berdasarkan perhitungan diperoleh agka t penelitian sebesar $4.751<\mathrm{t}$ tabel 1.6607 oleh karena itu maka H0 ditolak dan H1 diterima. Artinya ada hubungan linier antara click throught rates dengan keputusan pembelian.

\section{Uji Multikolineritas}

Untuk melihat gejala multikolineritas, kita dapat melihat dari hasil tabel statistik kolineritas. Hasil VIF yang lebih besar dari satu menunjukan adanya gejala multikolineritas. Dari hasil output tersebut terlihat bahwa nilai VIF tidak ada yang lebih dari 10. jadi dapat disimpulkan bahwa tidak tejadi multikolineritas antar variabel independen dalam model regresi.

Dari hasil perhitungan nilai tolerance juga menunjukan tidak ada variabel independen yang memiliki nilai tolerance kurang dari 0.1 yang berati tidak ada korelasi antara variabel independen

\section{Analisis Korelasi}

Korelasi antara faktor-faktor iklan online yang berpengaruh dapat dilihat pada tabel dibawah ini :

Untuk menafsir angka diatas digunakan kriteria sebagai berikut :

$0-0.25 \quad$ : korelasinya sangat lemah atau tidak ada

$0.25-0.5 \quad$ : korelasinya cukup kuat

$05-0.75 \quad$ : korelasinya kuat

$0.75-1 \quad$ : korelasinya sangat kuat 


\section{Tabel 6 Correlations}

\begin{tabular}{|ll|r|r|r|}
\hline \multicolumn{1}{|c|}{ Correlations } & \multicolumn{2}{c|}{$\begin{array}{c}\text { Click Throught } \\
\text { RatesX3 }\end{array}$} \\
\hline Attitude towards & $\begin{array}{r}\text { Attitude towards } \\
\text { the advertising X1 }\end{array}$ & Ad RecalX2 & $.479^{* * *}$ \\
the advertising X1 & Pearson Correlation & 1 & $.375^{* *}$ & .000 \\
& Sig. (1-tailed) & 100 & .000 & 100 \\
& $\mathrm{~N}$ & $.375^{* *}$ & 100 & $.482^{*}$ \\
Ad RecallX2 & Pearson Correlation & .000 & 1 & .000 \\
& Sig. (1-tailed) & 100 & 100 & 100 \\
& $\mathrm{~N}$ & $.479^{* *}$ & $.482^{* *}$ & 1 \\
\hline Click Throught & Pearson Correlation & .000 & .000 & 100 \\
RatesX3 & Sig. (1-tailed) & 100 & 100 & \\
& $\mathrm{~N}$ & & & \\
\hline
\end{tabular}

**. Correlation is significant at the 0.01 level (1-tailed).

Dari sekian banyak data diatas yang mempunyai hubungan korelasi cukup kuat sebagai berikut :

1. Ad Recall dengan Click Throught Rates sebesar 0.482

2. Click Throught Rates dengan Attitude towards the advertising 0.479

3. Ad Recall dengan Attitude towards the advertising sebesar 0.375

Dan faktor yang lainnya tidak mempunyai hubungan korelasi yang kuat atau dapat dikatakan sangat lemah.

\section{Uji Heterokedastisitas}

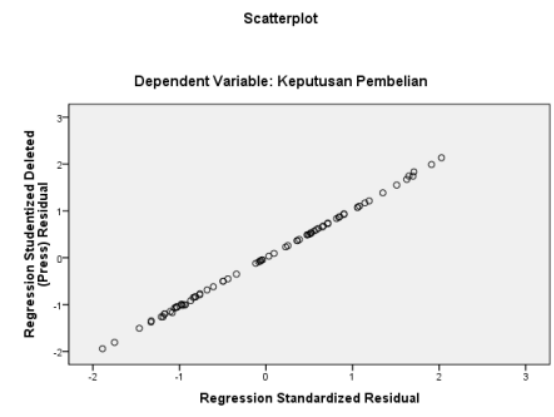

\section{Gambar 1 Uji Heterokedastisitas}

Dari hasil tersebut terlihat bahwa penyebaran residual adalah tidak teratur. Hal tersebut dapat dilihat dari plot yang terpencar dan tidak membentuk pola tertentu. Dengan hasil 
demikian, kesimpulan yang bias diambil adalah bahwa terjadi gejala homokedastisitas maka heterokedastisitas tidak terjadi

\section{Uji Normalitas}

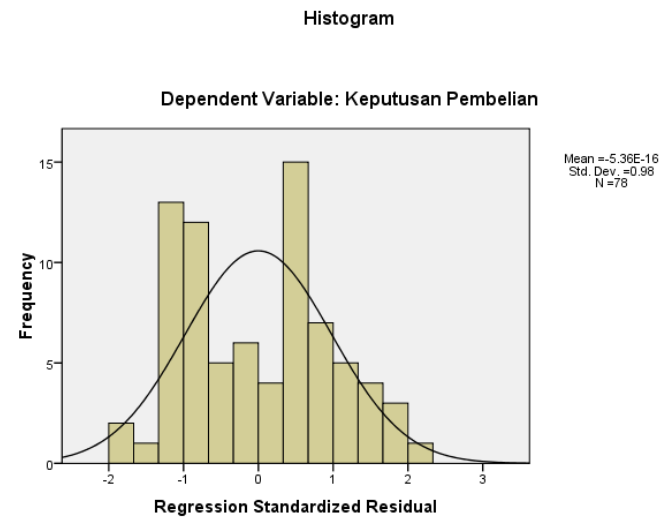

Normal P-P Plot of Regression Standardized Residual

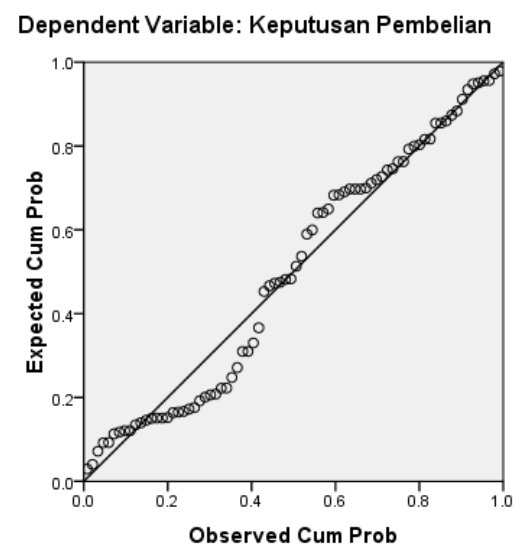

Gambar 2 Uji Normalitas

Untuk melihat apakah data terdistribusi normal atau tidak kita dapat melihat dari grafik histogram. Dari grafik output kita bisa melihat bahwa grafik Interpretasi Produk mengikuti bentuk distribusi normal dengan bentuk histogram, kita bisa melihat juga melalui P-Plots, suatu data akan terdistribusi normal jika nilai probabilitas yang di harapkan adalah sama dengan nilai probabilitas pengamatan. Pada grafik P-Plots, kesamaan antara nilai probabilitas harapan dan probabilitas pengamatan ditunjukan 
dengan garis diagonal yang merupakan perpotongan antara garis probabilitas harapan dan probabilitas pengamatan. Dari grafik terlihat bahwa nilai P-Plots terletak diantara garis diagonal. Jika kita lihat lebih jauh terlihat bahwa nilai P-Plots tidak menyimpang jauh dari garis diagonal, sehingga bisa diartikan bahwa data ini adalah normal.

\section{KESIMPULAN DAN SARAN}

\section{Kesimpulan}

a. Faktor attitude towards the advertising, ad recall dan click throught rates memiliki hubungan positif terhadap Keputusan Pembelian. Hubungan positif ini menunjukan bahwa faktor attitude towards the advertising, ad recall dan click throught rates memiliki pengaruh terhadap Keputusan Pembelian.

b. Dari penghitungan menggunakan Uji t atau secara parsial dapat disimpulkan bahwa dari attitude towards the advertising, ad recall dan click throught rates semuanya mempunyai pengaruh yang signifikan terhadap Keputusan Pembelian.

c. Dari ketiga faktor Ad Recall di instagram yang paling dominan pengaruhnya terhadap Keputusan Pembelian

\section{Saran}

Berdasarkan pada kesimpulan yang di ambil maka selanjutnya dapat diusulkan beberapa saran yang mungkin dapat dilakukan dan bermanfaat bagi pelaku UKM yang memasarkan produknya secara online. Adapun saran yang dapat diusulkan adalah sebagai berikut :

a. Ad Recall merupakan faktor paling dominan maka hendaknya pelaku UKM terus membuat program dan mempromosikan produknya agar tetap diingat dan direkomendasikan oleh pembeli.

b. Attitude towards the advertising dalah faktor yang berpengaruh signifikan kedua, hendaknya iklan yang ditampilkan disertai dengan respon cepat terhadap reaksi pembeli.

c. Pelaku UKM hendaknya mulai menyusun strategi promosi melalui media sosial secara serius sebab terbukti media sosial dapat meningkatkan penjualan produknya secara signifikan.

d. Perlunya mengikuti pelatihan promosi melalui media sosial dan cara pembuatan web guna meningkatkan pengetahuan pelaku UKM. 


\section{DAFTAR PUSTAKA}

Erdogmus, I. E., \& Çiçek, M. (2012). The impact of social media marketing on brand loyalty. Procedia - Social and Behavioral Sciences, 58:1353-1360.

Ghozali, Imam. 2009. Ekonometrika Teori, Konsep dan Aplikasi dengan SPSS 17. Badan Penerbit Universitas Diponegoro. Semarang.

Gujarati, Damodar, 2007. Ekonometrika Dasar, Jakarta: Erlangga.

Hening Ary Putra, 2014. Pengaruh Iklan Online Melalui Media Facebook Terhadap Keputusan Pembelian Pakaian Mahasiswa Fakultas Ekonomi dan Bisnis Universitas Trunajaya Madura. Jurnal Studi Manajemen, volume 8 nomor 1, April.

https://kominfo.go.id

http://www.antaranews.com/berita/540022/pengguna-instagram-indonesia-termasukterbanyak-di-dunia.

https://www.mediamasha.com

Kaplan, A.M. \& Haenlein. M. 2010. Users of The World. Unite! The Challenges and Oppurtunities of Social Media. Bussines Horizons.pp. 59-68.

Kotler, Philip. and K.L.Keller 2009. Manajemen Pemasaran. Edisi 13 Jilid 1. Erlangga.

Megawati. 2014. Pengaruh Iklan Online Pada Situs Jejaring Sosial Facebook Terhadap Keputusan Pembelian Online Pada Masyarakat Kota Padang. Jurnal Kajian Manajemen Bisnis, volume 3 nomor 2, September.

Mershon, P. (2011, November 8). Small Businesses Moving Toward Social Media. Retrieved March 2012, 7 from Social Media Examiner: http://www.socialmediaexaminer.com/26-promising- social-media-statsfor- smallbusinesses/. Diakes 28 Maret 2015 pukul 09.00.

Neti, Sisira. 2011. Social Media And Its Role In Marketing. International Journal of Volume 2 Nomor 4 Oktober 2014 Enterprise Computing and Business Systems ISSN . 1:1-15.

Nur Indriantoro. 2002. Metodologi Penelitian Bisnis. Yogyakarta : BPFE

Sugiyono, 2010. Metode Penelitian Kuantitatif. Bandung: Alfabeta

Teck - Chai Lau. 2011. The effectiveness of Online Advertisig in Purchase Decision : Liking, Recall and Click. Australian Journal of Basic and Apllied Sciences, 5 (9) : $1517-1524$. 